Arch. Tierz., Dummerstorf 51 (2008) 6, 549-559

Department of Animal Science, Biotechnical Faculty, University of Ljubljana, Ljubljana, Slovenia

DUŠANKA JORDAN, SILVESTER ŽGUR, GREGOR GORJANC and IVAN ŠTUHEC

\title{
Straw or hay as environmental improvement and its effect on behaviour and production traits of fattening pigs
}

\begin{abstract}
Fattening pigs are commonly kept in intensive housing systems with slatted floor which represent a very barren environment, causing poor animal welfare. To improve such conditions a small amount of straw or hay (100 g per animal per day laid daily in a rack) was used in our study as an environmental enrichment (EE). Two replications, each including 96 fattening pigs of both sexes ( 3 pens of 16 females and 3 pens of 16 male castrates) from $60 \mathrm{~kg}$ to slaughter at average $96 \mathrm{~kg}$ live weight, were used to test the effect of EE and sex on behaviour, growth rate, and carcass composition. EE significantly increased the proportion of total activity during the illumination period (between $6 \mathrm{a} . \mathrm{m}$. and $2 \mathrm{p}$. m.) on account of increased occupation with substrate $(\mathrm{P}<0.01)$. EE also significantly reduced time spent biting pen bars and frequency of aggressive encounters $(\mathrm{P}<0.01)$. The EE increased total activity in female animals during the observation period, but not in male castrates. None of the EE significantly influenced pigs' growth rate and lean meat percentage; however females in enriched environment grew slower and had greater lean meat percentage than the castrated males. Provision of a small amount of straw or hay to pigs in intensive housing systems can enrich barren environment in inexpensive and efficient way. Therefore such enrichment can be widely used also in large commercial pig production systems.
\end{abstract}

Keywords: pig, behaviour, housing, animal welfare, fattening and carcass traits

\section{Zusammenfassung}

Titel der Arbeit: Stroh oder Heu als Umweltverbesserung und ihr Einfluss auf das Verhalten und Produktionsmerkmale von Mastschweinen

Mastschweine werden üblicherweise intensiv auf Vollspaltenboden gehalten. Diese Form der Haltung ist reizarm und mindert das Wohlbefinden der Tiere. Um die Haltungsbedingungen zu verbessern, wurden zusätzlich zum Futter kleine Mengen Stroh bzw. Heu (100 g pro Tier und Tag) als Umweltanreicherung (UA) in Raufen angeboten. Es wurden zwei Wiederholungen mit jeweils 96 Mastschweinen beider Geschlechter (3 Buchten mit je 16 weiblichen sowie 3 mit je 16 kastrierten männlichen Tieren) durchgeführt. Die Mastschweine standen von $60 \mathrm{~kg}$ (Anfangsgewicht) bis zum Schlachtgewicht von $96 \mathrm{~kg}$ im Versuch. Geprüft wurde der Einfluss der UA und des Geschlechtes auf das Verhalten sowie die Gewichtzunahme und die Zusammensetzung des Schlachtkörpers der Tiere. Die UA durch Stroh bzw. Heu führte zu einer intensiven Auseinandersetzung mit diesen Substraten; sie hat die Gesamtaktivität der Tiere während der Helligkeitsphase des Stalles (6 bis 14 Uhr) insgesamt deutlich erhöht $(\mathrm{P}<0,01)$; gleichzeitig reduzierten sich die Dauer des Stangenbeißens und die Aggressionshäufigkeit wesentlich $(\mathrm{P}<0,01)$. Die UA erhöhte während der Beobachtungen die Gesamtaktivität bei weiblichen, aber nicht bei männlichen Tieren. Sie hat die tägliche Zunahme und den Fleischanteil im Schlachtkörper nicht beeinflusst. Allerdings zeigten weibliche Tiere ein langsameres Wachstum sowie einen höheren Fleischanteil als die Kastraten. Aus den Ergebnissen wird geschlossen, dass die Zufütterung von kleinen Mengen Stroh oder Heu in intensiven Haltungssystemen eine billige und wirksame Verbesserung der Haltungsbedingungen darstellt. Auch in größeren Schweinemastbetrieben könnte eine solche UA zweifellos kostengünstig eingesetzt werden. 


\section{Introduction}

Animal welfare research has been considerably intensified during the last years (SMIDT, 1992; SMIDT et al., 1995; TUCHSCHERER and MANTEUFFEL, 2000; WEBER and VALLE ZÁRATE, 2005). The present investigation will contribute to this topic. Pigs spend a considerable amount of time chewing the substrates in its environment (JENSEN et al., 1993). However, in a barren environment lacking the appropriate rooting substrates, pigs redirect their oral activities to the nearest substitutes, mostly pen fixtures and pen mates (BEATTIE et al., 2001). The result is increased harmful social behaviour, aggressiveness, and behaviours directed to pen equipment. The mentioned problems can be alleviated with appropriate environmental enrichment. Objects and substrates which are enriching the environment and liked by pigs should be chewable, deformable, destructible, odorous, and ingestible (VAN DE WEERD et al., 2003). It is also important that such enrichment should occupy animals for a longer period (SAMBRAUS, 1997; FRANKE, 2003). Substrates such as straw meet these requirements of variability and responsiveness. The "recreational" effect is a major potential benefit for the welfare of growing pigs, for it serves as a stimulus and outlet for rooting and chewing activities (FRASER et al., 1991).

The influence of environmental enrichment on pigs' welfare in intensive housing systems is well known. In slatted floor systems enrichment with raw material has not been used due to a high risk of blockage of the dunging canal under the slatted floor. Small amount of raw material provided in a way that it would not cause the blockage of the dunging canal and which would occupy animals for a longer time would therefore be appreciated. It is also not known if the enrichment is of the same importance for female and castrated male fattening pigs. Additionally, we wanted to find out if hay as environmental enrichment has the same beneficial influences on pigs as straw, because in some agricultural areas hay is more available than straw. The aim of this study was to find out if the addition of small amount of straw or hay is an appropriate way to enrich slatted floor pens and if it has the same effect on the behaviour and production of female and castrated male fattening pigs.

\section{Materials and methods}

\section{Animals}

The research was performed in two replications on a commercial pig farm. Each of two replications lasting seven weeks included 96 fattening pigs from $60 \mathrm{~kg}$ live weight to slaughter at average $96 \mathrm{~kg}$ live weight. The animals were housed in six slatted floor pens $(4.90 \times 2.45 \mathrm{~m})$ divided with full fences (Figure 1) containing 16 pigs each (three pens of females and three pens of male castrates). All animals were tail docked. They were fed on average with $2.4 \mathrm{~kg}$ of complete mixture of feedstuffs $(12.9 \mathrm{MJ} / \mathrm{kg} \mathrm{ME}, 14 \% \mathrm{CP})$ at $60 \mathrm{~kg}$ live weight with gradual increase up to $3.0 \mathrm{~kg}$ at the end of fattening period and 4 litres of fresh whey per animal and day. The complete mixture of feedstuffs and fresh whey were offered at $7.30 \mathrm{a} . \mathrm{m}$. and $12.00 \mathrm{p} . \mathrm{m}$. Mixture of feedstuffs was given first, but pigs did not start to eat until whey was poured in the troughs and moistened the mixture. Animals did not eat the whole meal at once but left a part of it for later, so feeding was practically ad libitum. Each day one third of the animals received $100 \mathrm{~g}$ of wheat straw per animal, the other third was given $100 \mathrm{~g}$ of hay per animal and one third of the animals were treated as a control group. Hay or straw was laid in the rack placed above the trough right after 
morning feeding of mixture of feedstuffs. The rack had a triangular profile and measured $115 \times 50 \mathrm{~cm}$ (Figure 2). The lower edge of the rack was $35 \mathrm{~cm}$ above the floor. The front side was made of $5 \times 5 \mathrm{~cm}$ wire mesh, which enabled animals to draw blades of hay or straw from the rack. At the beginning of experiment, pigs drew large wisps of hay or straw from the top of the racks, which caused blockage of the dunging canal under the slatted floor. To prevent this, an elastic band was stretched over straw or hay from one short side of the rack to the other. The lights in the pig house were on during working hours, namely from $6.00 \mathrm{a} . \mathrm{m}$. to $2.00 \mathrm{p} . \mathrm{m}$., when the farm workers performed everyday tasks.

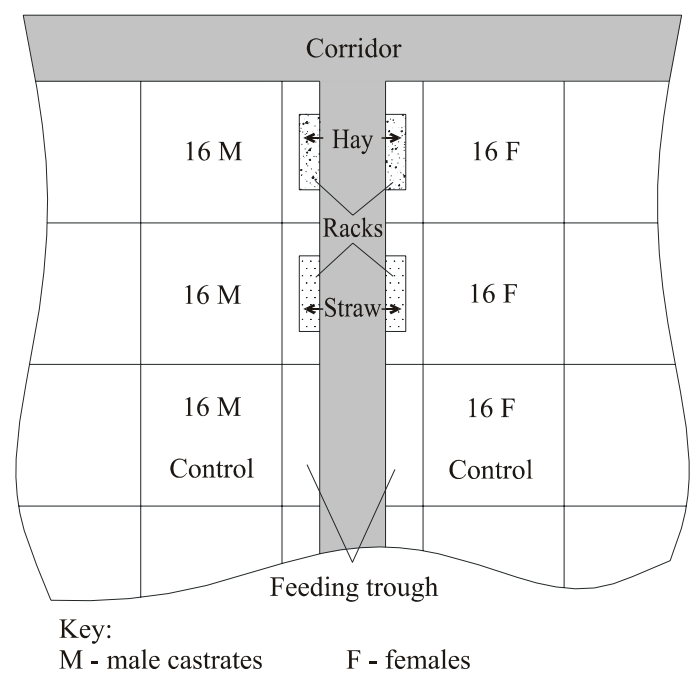

Fig. 1: Ground plan of experimental pens (Der Grundriss der Versuchsbuchten)

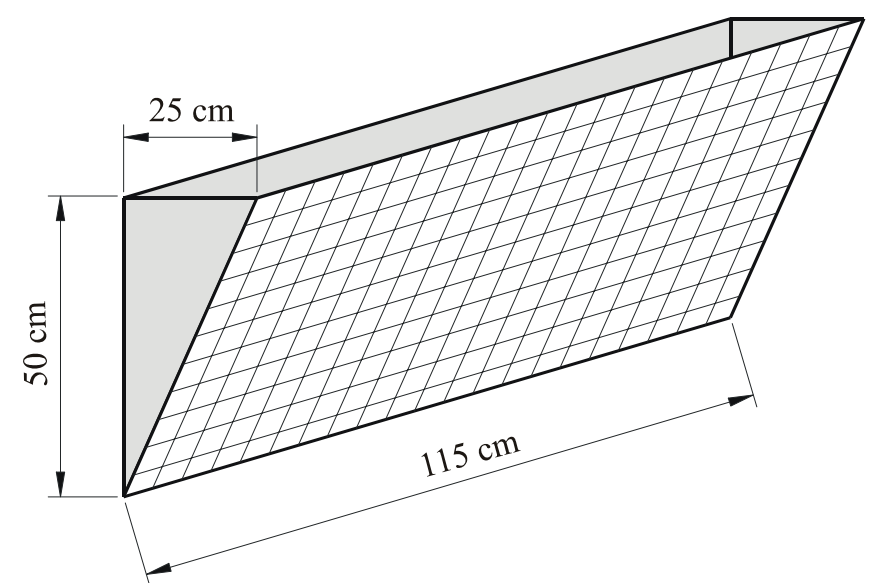

Fig. 2: The sketch of the rack used for straw or hay (Skizze der Raufe für das Stroh oder das Heu)

\section{Behavioural observations}

All the animals were marked with a four-digit number tattoo on their backs for the identification purpose. The first digit represented the treatment $(0-$ control group, 1 - straw group, 2 - hay group), the second one meant pig's sex (1 - male castrate, 2 - female), and the last two digits were the running number of the animal within treatment and sex (from 01 to 16).

Pigs were observed by direct observation for three days during light period lasting 8 hours in each replication. Observations were performed on day 10, 25, and 40 of each replication. Due to a large number of observed animals the observations were 
performed by two observers. At the same time each observer recorded the behaviour of pigs in three pens which were switched between them over the observation days. Long-term behavioural elements: resting (lying or sitting), feeding, chewing straw or hay, and biting pen bars were recorded by instantaneous sampling (MARTIN and BATESON, 1993) in 56 intervals per observation period (between $6.00 \mathrm{a} . \mathrm{m}$. and 2.00 p.m.). Long-term elements were mutually exclusive (feeding, chewing straw or hay, and biting pen bars were recorded only in standing position) and expressed as the percentage of observation period per animal. Total activity was defined as a sum of all long term behavioural elements except resting. Because total activity and resting always sum up to $100 \%$, only the results for total activity are presented. Short-term activities: drinking and aggressive encounters (aggressive and other injurious behaviour) were recorded continuously (MARTIN and BATESON, 1993) as group events when they occurred and expressed as frequency per pen and observation period. Altogether, 576 records (two replications, three treatments each with 16 females and 16 male castrates per replication and three observation days per replication) were collected for long-term behavioural elements and 36 records (two replications, three treatments each with one pen of females and one pen of male castrates per replication and three observation days per replication) for short-term activities.

\section{Growth rate and lean meat percentage}

Individual live weight of animals was measured twice, at the beginning of experiment, before the housing in pens and just before slaughter. Lean meat percentage was estimated according to Slovenian regulation. Altogether, 192 records (two replications, three treatments each with 16 females and 16 male castrates per replication) were available for daily gain and lean meat percentage.

\section{Statistics}

Data analysis was conducted using statistical program package SAS (SAS, 2001). Feeding, chewing of straw or hay and total activity were assumed to be normally distributed and analysed with a general linear model (1) in GLM procedure. Model (1) included fixed effect of replication $\left(R_{i}\right)$ with two levels, treatment $\left(T_{j}\right)$ with three levels, sex $\left(S_{k}\right)$ with two levels, and observation day within replication $\left(D_{i l}\right)$ with three levels. Biting pen bars and short-term activities (drinking and aggressive encounters) were not normally distributed. We assumed Poisson distribution for these traits and used generalized linear model (2) (McCULLAGH and NELDER, 1989) with default log link on expected value $\left(\lambda_{i j k l}\right)$ using GENMOD procedure and GLIMMIX macro. Model (2) included the same set of effects as model (1). Growth rate of pigs and lean meat percentage were also assumed to be normally distributed and analysed with model (3). Significant interactions were also included in the models, if their inclusion improved the fit of the model for at least one analysed trait. Multiple comparison adjustment test by Scheffe (SAS, 2001) was used. Results for drinking and aggressive encounters were analysed with pen as a unit and presented on observed scale (event frequency), whereas other behavioural elements were analysed with animal as a unit and presented as percentage of observation period per animal. Only the results for the effect of treatment, sex, and interaction between 
treatment and sex are presented because these effects were the main objective of our research.

$$
\begin{aligned}
& y_{i j k l m} \sim \operatorname{Normal}\left(\mu_{i j k l}, \sigma_{e}^{2}\right) \\
& \mu_{i j k l}=\alpha+R_{i}+T_{j}+S_{k}+D_{i l}+R T_{i j}+R S_{i k}+T S_{j k} \\
& y_{i j k l m} \sim \operatorname{Poisson}\left(\lambda_{i j k l}\right) \\
& \log \left(\lambda_{i j k l}\right)=\alpha+R_{i}+T_{j}+S_{k}+D_{i l}+R T_{i j}+R S_{i k}+T S_{j k} \\
& y_{i j k l} \sim \operatorname{Normal}\left(\mu_{i j k}, \sigma_{e}^{2}\right) \\
& \mu_{i j k}=\alpha+R_{i}+T_{j}+S_{k}+R S_{i k}+T S_{j k}
\end{aligned}
$$

\section{Results}

\section{Behaviour}

Pigs spent most of the observation period resting. On average they were active only from 23 to $27 \%$ of the observation period (Table 1 ).

\begin{tabular}{|c|c|c|c|}
\hline \multirow{2}{*}{ Behavioural elements } & \multicolumn{3}{|c|}{ Treatment } \\
\hline & Control & Straw & Hay \\
\hline \multicolumn{4}{|l|}{ Long-term: } \\
\hline \multicolumn{4}{|l|}{ Feeding } \\
\hline Average & $20.97 \pm 0.34^{\mathrm{a}}$ & $19.84 \pm 0.34^{\mathrm{ab}}$ & $18.78 \pm 0.34^{\mathrm{b}}$ \\
\hline Male castrates & $19.90 \pm 0.49^{\mathrm{a}}$ & $18.19 \pm 0.49^{\mathrm{abx}}$ & $17.28 \pm 0.49^{b x}$ \\
\hline Females & $22.04 \pm 0.49$ & $21.48 \pm 0.49^{\mathrm{y}}$ & $20.28 \pm 0.49^{\mathrm{y}}$ \\
\hline \multicolumn{4}{|l|}{ Chewing straw or hay } \\
\hline Average & / & $5.63 \pm 0.28^{\mathrm{a}}$ & $7.13 \pm 0.28^{b}$ \\
\hline Male castrates & l & $4.37 \pm 0.38^{x}$ & $5.80 \pm 0.39^{x}$ \\
\hline Females & l & $6.89 \pm 0.39^{\mathrm{y}}$ & $8.47 \pm 0.41^{\mathrm{y}}$ \\
\hline \multicolumn{4}{|l|}{ Biting pen bars } \\
\hline Average & $2.56 \pm 0.16^{\mathrm{a}}$ & $0.52 \pm 0.07^{\mathrm{b}}$ & $0.35 \pm 0.06^{\mathrm{b}}$ \\
\hline Male castrates & $2.27 \pm 0.21^{\mathrm{a}}$ & $0.48 \pm 0.10^{\mathrm{b}}$ & $0.24 \pm 0.07^{b}$ \\
\hline Females & $2.90 \pm 0.24^{\mathrm{a}}$ & $0.56 \pm 0.10^{b}$ & $0.52 \pm 0.10^{\mathrm{b}}$ \\
\hline \multicolumn{4}{|l|}{ Total activity $^{1}$} \\
\hline Average & $23.56 \pm 0.44^{\mathrm{a}}$ & $26.23 \pm 0.44^{\mathrm{b}}$ & $27.12 \pm 0.44^{\mathrm{b}}$ \\
\hline Male castrates & $22.17 \pm 0.62$ & $23.05 \pm 0.62^{\mathrm{x}}$ & $23.79 \pm 0.62^{x}$ \\
\hline Females & $24.94 \pm 0.62^{\mathrm{a}}$ & $29.41 \pm 0.62^{\text {by }}$ & $30.45 \pm 0.62^{\text {by }}$ \\
\hline \multicolumn{4}{|l|}{ Short-term: } \\
\hline \multicolumn{4}{|l|}{ Drinking } \\
\hline Average & $12.14 \pm 0.54$ & $10.86 \pm 0.52$ & $12.77 \pm 0.56$ \\
\hline Male castrates & $12.30 \pm 0.77$ & $9.84 \pm 0.69$ & $11.97 \pm 0.76$ \\
\hline Females & $11.97 \pm 0.76$ & $11.97 \pm 0.76$ & $13.61 \pm 0.81$ \\
\hline \multicolumn{4}{|l|}{ Aggressive encounters } \\
\hline Average & $9.66 \pm 0.86^{\mathrm{a}}$ & $3.67 \pm 0.52^{b}$ & $2.59 \pm 0.44^{b}$ \\
\hline Male castrates & $7.91 \pm 1.09^{\mathrm{a}}$ & $2.79 \pm 0.63^{b}$ & $2.02 \pm 0.53^{b}$ \\
\hline Females & $11.79 \pm 1.32^{\mathrm{a}}$ & $4.82 \pm 0.84^{\mathrm{b}}$ & $3.32 \pm 0.70^{\mathrm{b}}$ \\
\hline
\end{tabular}

Table 1

LSQ means \pm standard error of long-term behavioural elements (percentage of observation period per animal) and short-term activities (frequency per pen in observation period) per treatment and sex (LSQ Mittelwerte \pm Standardfehler bei Langzeitverhaltensmerkmalen [Anteil der Beobachtungsperiode pro Tier] und Kurzzeitaktivitäten [Häufigkeit pro Bucht in der Beobachtungsperiode] nach Behandlung und Geschlecht)

\footnotetext{
${ }^{a, b}$ Values with different superscripts within a row are significantly different between treatments $(\mathrm{P}<0.05)$.

${ }^{\mathrm{x}, \mathrm{y}}$ Values with different superscripts within a column within each activity are significantly different between $\operatorname{sexes}(\mathrm{P}<0.05)$.

${ }^{1}$ Total activity is a sum of feeding, chewing straw or hay and biting pen bars.
} 
The major part of active time was spent for feeding. The addition of straw or hay significantly influenced all observed behaviours, except drinking. Pigs in a control group spent significantly less time for total activity in comparison with animals in both experimental groups. Percentage of time spent eating the complete mixture of feedstuffs was also greater in the control group. The differences between the control and hay treatment were significant $(\mathrm{P}<0.01)$, whereas between the control and straw group a trend of differences was noticed $(\mathrm{P}=0.067)$. Pigs chewed hay for a greater percentage of observation periods than straw. Both substrates significantly reduced the percentage of time pigs spent biting pen bars and it also significantly reduced

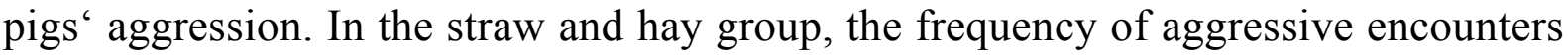
among pigs was significantly lower than in the control group.

Between sexes in the control group there were no significant differences in the percentage of time spent feeding, biting pen bars, and for total activity, as well as in frequency of drinking and aggressive encounters. Nevertheless, in two activities a trend of differences between females and male castrates was noticed (feeding $\mathrm{P}=0.087$ and total activity $\mathrm{P}=0.079$ ). In straw and hay group females showed significantly more total activity than male castrates, which also spent significantly less time feeding. In time spent chewing straw or hay there were significant differences between sexes, too. Females spent more time chewing than castrated males. At the end of observation at 2.00 p.m., male castrates still had some chewing material in their racks, but the racks in females' pens were already empty.

\section{Growth rate and lean meat percentage}

The addition of straw or hay had no significant influence on pigs' growth rate during finishing period and lean meat percentage (Table 2), whereas sex of the animals significantly influenced both traits. Females in the hay group had significantly smaller growth rate than male castrates, but in the straw group a trend of differences was noticed $(\mathrm{P}=0.058)$. In both experimental groups females also had greater percentage of lean meat.

Table 2

LSQ means \pm standard error of growth rate and lean meat percentage of pigs per treatment and sex (LSQ Mittelwerte \pm Standardfehler für tägliche Zunahme und Fleischanteil der Mastschweine nach Behandlung und Geschlecht)

\begin{tabular}{lccc}
\hline & Control & $\begin{array}{c}\text { Treatment } \\
\text { Straw }\end{array}$ & Hay \\
\hline Growth rate, g/day & & & \\
$\quad$ Average & $765 \pm 10$ & $759 \pm 10$ & $773 \pm 10$ \\
Male castrates & $793 \pm 14$ & $793 \pm 15$ & $810 \pm 14^{\mathrm{x}}$ \\
$\quad$ Females & $737 \pm 4$ & $725 \pm 14$ & $736 \pm 15^{\mathrm{y}}$ \\
Lean meat percentage, $\%$ & & \\
$\quad$ Average & $53.68 \pm 0.38$ & $53.46 \pm 0.38$ & $53.75 \pm 0.38$ \\
$\quad$ Male castrates & $52.86 \pm 0.53$ & $52.16 \pm 0.53^{\mathrm{x}}$ & $52.44 \pm 0.53^{\mathrm{x}}$ \\
$\quad$ Females & $54.50 \pm 0.53$ & $54.75 \pm 0.53^{\mathrm{y}}$ & $55.07 \pm 0.53^{\mathrm{y}}$ \\
\hline${ }^{\mathrm{x}, \mathrm{y}}$ Least square means with different superscripts within a column within each trait are significantly different between sexes $(\mathrm{P}<0.05)$.
\end{tabular}

\section{Discussion}

\section{Behaviour}

The daily addition of $100 \mathrm{~g}$ of straw or hay per animal laid in a rack resulted in significant behavioural differences compared to the non-enriched treatment, as found 
by KELLEY et al. (2000) with $50 \mathrm{~g}$ of straw per animal daily. It seems that only a small amount of straw is required to provide welfare benefits, but it has to be daily renewed to preserve its effect of novelty and attract pigs' attention (FRASER et al., 1991; WHITTAKER et al., 1998; KELLEY et al., 2000; MOINARD et al., 2003). Straw or hay laid in the rack increased the proportion of time animals were active. Similar results were also reported by AREY and FRANKLIN (1995) and GUY et al. (2002), who reported that pigs in straw yards spent significantly less time lying inactive and more time lying active compared to those in fully slatted pens. However, in the present experiment, increased proportion of total activity was noticed only in females, and not in male castrates. Increased total activity of pigs observed in experimental groups occurred on account of their interest and occupation with straw or hay. Pigs, having the opportunity to manipulate loose stimuli in their environment, perform this behaviour during great part of their active time (VAN PUTTEN, 1980; PETERSEN et al., 1995; BEATTIE et al., 2000; ROHRMANN and HOY, 2004). Besides, straw and hay have all characteristics of substrates the pigs should have (VAN DE WEERD et al., 2003) to reinforce their exploratory and feeding motivation (DAY et al., 2002b). We observed that the racks with hay were empty earlier than the racks with straw in both sexes. However, pigs chewed hay for a greater percentage of observation periods (Table 1).

These two facts indicate that straw might be better enrichment in comparison to hay, because it lasts longer as chewing material. Female animals were occupied with hay and straw for a greater proportion of the observation period compared to male castrates. It seems they had a greater motivation for chewing. At the end of observation day male castrates still had some straw in the racks, which were empty the next morning. From this it can be concluded that male castrates continued chewing straw after the end of observation, also during the dark period of the day. Both substrates, hay and straw, given to the pigs, had a role of an environmental enrichment and improved animal welfare. Occupation with straw or hay resulted in lower percentage of time spent biting pen bars and lower frequency of aggressive encounters, which is in accordance with several studies (FRASER et al., 1991; LYONS et al., 1995; BEATTIE et al., 1996, 2001; O`CONNELL and BEATTIE, 1999; KELLY et al., 2000; DAY et al., 2002a).

On the basis of this result it can be also presumed, that it is not urgently required to enable the access to racks filled with straw or hay to all pigs at the same time as practiced in the case of feeding trough. The $115 \mathrm{~cm}$ long rack of straw or hay as environmental enrichment provided all 16 pigs the opportunity to draw blades of straw or hay from the rack without causing the increment of aggressive encounters among pen mates. Straw or hay also decreased the percentage of feeding time although several previous studies reported no significant influence of environmental enrichment on time spent or frequency of feeding (BEATTIE et al., 1996; GUY et al., 2002), and feeding pattern (FRASER et al., 1991). In the present study significantly decreased time of feeding during the observations was noticed only for male castrates in the hay group. Pigs in the hay and straw group had still some complete mixture of feedstuffs in their troughs at the end of daily observation at $2.00 \mathrm{p} . \mathrm{m}$. It seems that in this case chewing of straw or hay had a feeding and recreational effect (FRASER et al., 1991), which lowered pigs' motivation for the consumption of complete mixture of feedstuffs. The frequency of drinking was not influenced by 
treatment, which is in accordance with findings of BEATTIE et al. (1996) and WHITTAKER et al. (1998), who studied the effect of provision of straw on sows.

Females seemed to be more active than male castrates, for they spent greater percentage of the observation period feeding and chewing straw or hay. These results are only partly in accordance with findings of GONYOU et al. (1992). They found that the only sex difference in barren environment was in time spent lying. Namely, barrows spent more time lying and less time standing than gilts. VARGAS VARGAS et al. (1987) observed higher social rank and more aggressive acts at gilts than at castrated males in mixed groups. Although male castrates in the present study chewed given substrate significantly less than females, they also reduced the frequency of biting pen bars and aggressive encounters in straw and hay group. This demonstrates improved animal welfare due to chewing substrate also in less active gender.

\section{Growth rate and lean meat percentage}

The addition of straw or hay did not influence pigs' growth rate, probably due to too small amount of offered substrate per animal. MORGAN et al. (1998) and BEATTIE et al. (2000) reported increased growth rate in pigs that had environmental enrichment in the form of straw bedding. Conflicting results appear also in other studies, where authors did not use straw as environmental enrichment but different kind of toys, such as car tires (SCHAEFER et al., 1990) chains (PEARCE et al., 1989; PEARCE and PATERSON, 1993; HILL et al., 1998), cloth strips, lifter bars, swivel wheels, dustbin lids (PEARCE and PATERSON, 1993) and a rubber hose (HILL et al., 1998). SCHAEFER et al. (1990) found that enriched environment improved pigs' growth rate, whereas PEARCE et al. (1989), PEARCE and PATERSON (1993), BLACKSHAW et al. (1997), and HILL et al. (1998) found no improvement in productivity when pigs were in enriched environment.

Straw or hay had no significant influence on lean meat percentage of pigs included in the experiment. In accordance with the present results are findings of HILL et al. (1998), who enriched pigs' environment with metal chains and rubber hose, and BEATTIE et al. (2001), who as an environmental enrichment used mushroom compost. They reported no significant effect of environmental enrichment on carcass fatness. On the contrary, some studies reported that pigs with straw and peat enriched environment had a greater growth rate (BEATTIE et al., 2000) or live weight (O'CONNELL et al., 2004), and heavier carcass weight with greater level of back fat thickness due to greater feed intake and better feed conversion (BEATIE et al., 2000). Sex of the animals significantly influenced growth rate in the hay group, but in the straw group a trend of differences was noticed. Furthermore, in the straw and hay group significant differences were also observed in lean meat percentage. Females grew slower and had greater lean meat percentage. It is a well-known fact that castrated males grow faster than females due to their greater ability of feed consumption (PURCHAS, 1991; OLSSON et al., 2003) and produce fatter carcasses with lower lean meat percentage than females (PURCHAS, 1991; STEINBERG et al., 1992; BIEDERMANN et al., 2000; OLSSON et al., 2003; LATORE et al, 2004). However, in our study both sexes had the same feed consumption. The possible explanation for the observed sex differences in growth rate and lean meat percentage in enriched groups could be also the greater total activity of female animals (Table 1). 
In conclusion small daily amount of straw or hay offered in racks served as an environmental enrichment and improved welfare of fattening pigs housed in a fully slatted floor pen. Both substrates reduced biting pen bars and aggressiveness among pigs, which are known as behavioural disorders in intensive housing systems, but did not influence growth rate and lean meat percentage of pigs. Significant sex differences were observed in pigs' behaviour as well as in their daily gains and lean meat percentage. Provision of straw or hay significantly increased total activity of female animals during the observation period, but this was not observed in male castrates. Females in enriched environment grew slower and had greater lean meat percentage than castrated males. Provision of a small amount of straw or hay to pigs in intensive housing systems can enrich barren environment in inexpensive and efficient way. Therefore such enrichment can be widely used also in large commercial pig production systems to improve animal welfare.

\section{Acknowledgments}

We are grateful to Mrs Karmela Malinger for proof reading the manuscript as well as to two referees that provided valuable comments on the earlier version of the manuscript, and Kristijan Hrastar and Matej Šušteršič for technical assistance and observation of the animals.

\section{References}

AREY, D.S.; FRANKLIN, M.F.:

Effects of straw and unfamiliarity on fighting between newly mixed growing pigs. Appl. Anim. Behav. Sci. 45 (1995), 23-30

BEATTIE, V.E.; O`CONNELL, N.E.; MOSS, B.W.:

Influence of environment enrichment on the behaviour, performance and meat quality of domestic pigs. Livest. Prod. Sci. 65 (2000), 71-79

BEATTIE, V.E.; SNEDDON, I.A.; WALKER, N.; WEATHERUP, R.N.:

Environmental enrichment of intensive pig housing using spent mushroom compost. Anim. Sci. 72 (2001), 35-42

BEATTIE, V.E.; WALKER, N.; SNEDDON, I.A.:

An investigation of the effect of environmental enrichment and space allowance on the behaviour and production of growing pigs. Appl. Anim. Behav. Sci. 48 (1996), 151-158

BIEDERMANN, G.; JATSCH, C.; PESCHKE, W.; LINDNER, J.-P.; WITTMANN, W.:

Mast- und Schlachtleistung sowie Fleisch- und Fettqualität von Pietrain-Schweinen unterschiedlichen MHS-Genotyps und Geschlechts. I.: Mast- und Schlachtleistung sowie Fleischqualität. Arch. Tierz. 43 (2000), 151-164

BLACKSHAW, J.K.; THOMAS, F.J.; LEE, J.A.:

The effect of a fixed or free toy on the growth rate and aggressive behaviour of weaned pigs and the influence of hierarchy on initial investigation of the toys. Appl. Anim. Behav. Sci. 53 (1997), 203-212

DAY, J.E.L.; BURFOOT, A.C.; DOCKING, M.; WHITTAKER, X.; SPOOLDER, H.A.M.; EDWARDS, S.A.: The effects of prior experience of straw and the level of straw provision on the behaviour of growing pigs. Appl. Anim. Behav. Sci. 76 (2002a), 189-202

DAY, J.E.L.; SPOOLDER, H.A. M.; BURFOOT, A.; CHAMBERLAIN, H.L.; EDWARDS, S.A.:

The separate and interactive effects of handling and environmental enrichment on the behaviour and welfare of growing pigs. Appl. Anim. Behav. Sci. 75 (2002b), 177-192

FRANKE, W.:

Haltungslösungen für Schweine - Entwicklungsrichtungen und Praxisumsetzung. Arch. Tierz. 46 (2003) Sonderheft, 43-47

FRASER, D.; PHILIPS, P.A.; THOMPSON, B.K.; TENNESSEN, T.:

Effect of straw on the behaviour of growing pigs. Appl. Anim. Behav. Sci. 30 (1991), 307-318 
GONYOU, H.W.; CHAPPLE, R.P.; FRANK, G.R.:

Productivity, time budgets and social aspects of eating in pigs penned in groups of five or individually. Appl. Anim. Behav. Sci. 34 (1992), 291-301

GUY, J.H.; ROWLINSON, P.; CHADWICK, J.P.; ELLIS, M.:

Behaviour of two genotypes of growing-finishing pig in three different housing systems. Appl. Anim. Behav. Sci. 75 (2002), 193-206

HILL, J.D.; McGLONE, J.J.; FULLWOOD, S.D.; MILLER, M.F.:

Environmental enrichment influences on pig behaviour, performance and meat quality. Appl. Anim. Behav. Sci. 57 (1998), 51-68

JENSEN, M.B.; KYRIAZAKIS, I.; LAWRENCE, A.B.:

The activity and straw directed behaviour of pigs offered foods with different crude protein content. Appl. Anim. Behav. Sci. 37 (1993), 211-221

KELLY, H.R.C.; BRUCE, J.M.; ENGLISH, P.R.; FOWLER, V.R.; EDWARDS, S.A.:

Behaviour of 3-week weaned pigs in Straw-Flow, deep straw and flatdeck housing systems. Appl. Anim. Behav. Sci. 68 (2000), 269-280

LATORRE, M.A.; LAZARO, R.; VALENCIA, D.G.; MEDEL, P.; MATEOS, G.G.:

The effects of gender and slaughter weight on the growth performance, carcass traits, and meat quality characteristics of heavy pigs. J. Anim. Sci. 82 (2004), 526-533

LYONS, C.A.P.; BRUCE, J.M.; FOWLER, V.R.; ENGLISH, P.R.:

A comparison of productivity and welfare of growing pigs in four intensive systems. Livest. Prod. Sci. 43 (1995), 265-274

MARTIN, P.; BATESON, P.:

Measuring behaviour: an introductory guide. $2^{\text {nd }}$ ed., Cambridge (1993)

McCULLAGH, P.; NELDER, J.A.:

Generalized linear model. $2^{\text {nd }}$ ed. Boca Raton (1989)

MOINARD, C.; MENDL, M.; NICOL, C.J.; GREEN, L.E.:

A case control study of on farm risk factors for tail biting in pigs. Appl. Anim. Behav. Sci. 81 (2003), 333-355

MORGAN, C.A.; DEANS, L.A.; LAWRENCE, A.B.; NIELSE, B.L.:

The effect of straw bedding on the feeding and social behaviour of growing pigs fed by means of single-space feeders. Appl. Anim. Behav. Sci. 58 (1998), 23-33

O`CONNELL, N.E.; BEATTIE, V.E.:

Influence of environment enrichment on aggressive behaviour and dominance relationships in growing pigs. Anim. Welf. 8 (1999), 269-279

O‘CONNELL, N.E.; BEATTIE, V.E.; MOSS, B.W.

Influence of social status on the welfare of growing pigs housed in barren and enriched environments. Anim. Welf. 13 (2004), 425-431

OLSSON, V.; ANDERSSON, K.; HANSSON, I.; LUNDSTRÖM, K.:

Differences in meat quality between organically and conventionally produced pigs. Meat Sci. 64 (2003), 287-297

PEARCE, G.P.; PATERSON, A.M.:

The effect of space restriction and provision of toys during rearing on the behaviour, productivity and physiology of male pigs. Appl. Anim. Behav. Sci. 36 (1993), 11-28

PEARCE, G.P.; PATERSON, A.M.; PEARCE, A.N.:

The influence of pleasant and unpleasant handling and the provision of toys on the growth and behaviour of male pigs. Appl. Anim. Behav. Sci. 23 (1989), 27-37

PETERSEN, V.; SIMONSEN, H.B.; LAWSON, L.G.:

The effect of environmental stimulation on the development of behaviour in pigs. Appl. Anim. Behav. Sci. 45 (1995), 215-224

PURCHAS, R.W.:

Effect of sex and castration on growth and composition, in PEARSON, A.M. (ed.): Growth regulation in farm animals. Barking (1991), 203-254

ROHRMANN, S.; HOY, S.:

Ethologische Untersuchungen zur Beschäftigung von Ebern in Besamungsstationen mit Stroh. Arch. Tierz. 47 (2004), 565-574

SAMBRAUS, H.H.:

Tierverhalten - ein Anzeiger für eine artgerechte Tierhaltung. Arch. Tierz. 40 (1997) Sonderheft, 26-34

SAS:

The SAS system for Windows release 8.02. SAS Institute Incorporation, Cary (2001)

SCHAEFER, A.L.; SALOMONS, M.O.; TONG, A. K.W.; SATHER, A.P.; LEPAGE, P.:

The effect of environment enrichment on aggression in newly weaned pigs. Appl. Anim. Behav. Sci.

27 (1990), 41-52 
SMIDT, D.:

Schwerpunkte und Entwicklungstendenzen in der Nutztierforschung. Arch. Tierz. 35 (1992), 143-159

SMIDT, D.; SCHLICHTING, M.C.; LADEWIG, J.; STEINHARDT, M.:

Ethologische und verhaltensphysiologische Forschung für tiergerechte Nutztierhaltung. Arch. Tierz. 38 (1995), 7-19

STEINBERG, M.; HERTEL, B.; SIEGL, O.:

Nach Geschlechtern getrennte Mast von Schweinen-Beitrag zur marktgerechten Schlachtkörper struktur. Arch. Tierz. 35 (1992), 473-482

TUCHSCHERER, M.; MANTEUFFEL, G.:

Die Wirkung von psychischem Stress auf das Immunsystem. Ein weiterer Grund für tiergerechte Haltung. Arch. Tierz. 43 (2000), 547-560

VAN DE WEERD, H.A.; DOCKING, C.M.; DAY, J.E.L.; AVERY, P.J.; EDWARDS, S.A.:

A systematic approach towards developing environmental enrichment for pigs. Appl. Anim. Behav. Sci. 84 (2003), 101-118

VAN PUTTEN, G.:

Objective observations on the behaviour of fattening pigs. Anim. Regul. Stud. 3 (1980), 105-118

VARGAS VARGAS, J.; CRAIG, J.V.; HINES, R.H.:

Effects of feeding systems on social and feeding behavior and performance of finishing pigs. J. Anim. Sci. 65 (1987), 463-474

WEBER, R.E.F.; VALLE ZÁRATE, A.:

Der Begriff Wohlbefinden in der Nutztierhaltung - Diskussion aktueller Definitionsansätze als Grundlage für praxisorientierte Forschung am Beispiel der Mastschweinehaltung. Arch. Tierz. 48 (2005), 475-489

WHITTAKER, X.; SPOOLDER, H.A.M.; EDWARDS, S.A.; LAWRENCE, A.B.; CORNING, S.:

The influence of dietary fibre and the provision of straw on the development of stereotypic behaviour in food restricted pregnant sows. Appl. Anim. Behav. Sci. 61 (1998), 89-102

Received: 2008-02-27

Accepted: 2008-08-26

Corresponding author:

Prof. Dr. IVAN ŠTUHEC

Department of Animal Science

Biotechnical Faculty

University of Ljubljana

Groblje 3

SI-1230 Domžale

Slovenia

email: ivan.stuhec@bfro.uni-lj.si 